\title{
Society and Sex Selection; Son Preference among the Educated Middle-Class in Kathmandu
}

\author{
Bishnu Prasad Dahal \\ Department of Anthropology, Patan Multiple Campus, Tribhuvan University, Patan Dhoka, Nepal \\ Email: phd.bishnudahal@gmail.com
}

How to cite this paper: Dahal, B. P. (2020). Society and Sex Selection; Son Preference among the Educated Middle-Class in Kathmandu. Advances in Anthropology, 10, 147-168.

https://doi.org/10.4236/aa.2020.102009

Received: April 7, 2020

Accepted: May 12, 2020

Published: May 15, 2020

Copyright $\odot 2020$ by author(s) and Scientific Research Publishing Inc. This work is licensed under the Creative Commons Attribution International License (CC BY 4.0).

http://creativecommons.org/licenses/by/4.0/ (c) (i) Open Access

\begin{abstract}
A cultural ecological perspective is valuable in identifying the complex relationship among ecology, culture, society, economy, demography and preference of particular gender especially male preferences. An evolutionary psychology explanation of female infanticide should take into account the role of cultural practices and ecological pressures in shaping psychological antecedents to treating differently even for own genes i.e. male preference and female neglect. In this regards, the relationship between ecology and culture is dynamic, and that macro interventions, such as building of cities, urbanization, development of highways, constructions of high dams in a physical development and advancement of socio-economic parameters associated with human development including leadership development, sustainability, sustainable use of resources, maintain equilibrium among population and resources and opportunities including empowerment of women, ultimately resulting in tightening the screw of social control of women's sexuality. There should be maintained delicate balance between the relationship between women-men, women-women, and men-men, economically, demographically, socially, physically ecologically biologically or say culturally symbiotic in various forms as a husband or a son or a brother. From the study, it is concluded that, though society and culture are modern, heterogeneous, complex, advancing the conservative or traditional practices of son preference or discrimination based on gender are still practiced and are prevalent in our society and continue to define gender roles and practices especially among the middle-classes that found in Kathmandu. Therefore, son preference, for the middle-class women in Kathmandu, should not be understood superficially. It is a complex whole and it should be studied critically in detail.
\end{abstract}

\section{Keywords}

Sex Selection, Son Performance, Ecology, Sociobiology, Economy, Demography 
Patriarchy, Middle Class, Female Feticide, Gender Discrimination

"To attempt to understand human behavior is .... the most exciting challenge in the world" (Milton M. Gordon, 1988).

\section{Introduction}

In anthropology, it is possible to identify the role of social environment on actions. The values and attitudes, activities, relationships of society are shaped by the structure of society composed of parts/elements.

Anthropologists' including most of the social scientists' theoretical and empirical analysis, have generally been based on the assumption that societies can be seen as persistent, cohesive, stable, generally integrated wholes differentiated by their cultural and social structural arrangements. Functionalism was compatible with the core features of structuralism. Both of these "isms" (one stresses on function and another on structure) support a holistic picture of society in which the interrelationship of sub-system and practices is central. Structuralists believe on those social systems to survive. They needed some how to adjust to their environment. Functional unity is held when all parts of the social system work together with a sufficient degree of harmony or internal consistency.

Kathmandu is heterogeneous society in terms of ecology, economy, culture, caste and ethnicity, gender, religion. Kathmandu is multilingual, multi-religious, multicultural and multi-ethnic valley. When we go back to the history of Kathmandu that we can find it out, it depends on syncretism of various cultures, languages, religions, castes and ethnics. It is a garden of all castes and ethnic groups.

Son preference is generally in justice concepts that are socially determined by their own bias perspectives. It is a biological choice which is constructed socio-culturally. In a patriarchal society, couples prefer to raise a child who has the culturally accepted characteristics, status and economic potential associated with the male gender. This preference often influences behavior and may result in gender biases that negatively affect girls' and women's welfare, health and survival. Thus, preference may lead to discrimination.

The patriarchal dominated Hindu, orthodox society of Nepal, prefers sex as it has received little attention, possibly because the overall sex ratio at birth (105) is similar to the expected value (Pradhan et al., 1997). In addition, Nepal is in the early stages of fertility decline; hence, sex-selective abortion is rare (Karki, 1992). However, the sex ratio at last birth in Nepal for women who claim to have completed their families or to have been sterilized is estimated at 146 , suggesting that stopping behavior among these women is driven by son preference (Pradhan et al., 1997).

In patriarchal society like in Nepal, son preference is promoted through its 
patriarchal ideology which favors sons over daughters and has led to the practice of female feticide in contemporary times. Female feticide refers to sex-detection of a fetus followed by an abortion if the fetus is found to be female. It is prevalent in many countries such as China, India, South Korea, and Vietnam (George, 1997). China has the lowest female child sex ratio in the world, followed by India. Many studies conducted at the global level and particularly within Asia which examine this imbalance in female-male sex ratios (Unnithan-Kumar, 2005).

In some countries with a strong sex preference, couples stop having children only when they are satisfied with the sex composition of their family (Dalla \& Leone, 2001)-typically, after the birth of a son. Consequently, the sex ratio of last-born children (sex ratio at last birth) can be much higher than the biological constant of 106 sons per 100 daughters ever born (sex ratio at birth, Das Gupta, 1987).

Though they have educational and financial resources, son preference is common in Nepal and in India. Sex/ gender based discriminations are not equally practiced uniformly across different class groups. People usually resort to sex-selective abortions and In Vitro Fertilization (IVF) techniques to have a son while keeping their family size small, often limited to two children (Mitra, 2014). On the other hand, people with less wealth usually have a higher fertility rate and a higher female child mortality rate, lower female literacy, higher female malnutrition, and are more likely to practice female infanticide in place of female feticide (Mitra, 2014).

I carried out my research in the urban regions of Kathmandu, in the years 2019 and 2020. In this article, I explore and present the son preference as it is experienced by educated urban married middle-class mothers from the Kathmandu Metropolitan City. The study explores society', men' and women's attitudes to son preference and how they frame the issue with the specific reasons and what are the exiting situation of treatment with their daughters within a rapidly changing social and economic context where son preference remains the cultural norm.

\section{Son Preference in Nepal}

Men handled and men lead societies of Nepal, are mainly patriarchal and patrilineal; that is, men are the heads of families and women join their husbands' families after their marriages. Based on the Hindu ideology, patriarchal beliefs, norms and values have resulted in different forms of gender disparity, inequalities and injustice. Despite several socio-cultural and legal reforms, various types of gender inequalities are still persistent in urban Nepal which is collective efforts of patriarchy, men and women; female feticide is still prevalent in our society as gender inequality.

Although female feticide is illegal under the prevailing existing law of Nepal (Puri et al., 2007), it is accepted legally, with some conditions by "The Right to 
Safe Motherhood and Reproductive Health Act 2018". According to the law, sex-selective abortions are procured illegally, leading to a constant decline in the female child sex ratio (Unnithan-Kumar, 2010). With the introduction of modern reproductive technologies, infanticide has been replaced by feticide, but in Nepal female infanticide was common in societies where dowry (gifts from parents and relatives, neighbors etc.) was praised and practiced, where only a few women were employed in the agriculture sector (Miller, 1997).

The effect of gender discrimination on children is basically analyzed by the study of the sex-specific child mortality rate, after correction for sex-determined disease susceptibility (girls are generally more resistant to disease than are boys) and for other gender-related differences (e.g., accidental deaths are more common among boys than among girls). Similarly, higher mortality rate of girls than that of boys indicates that caring of girls children were not got priority than compared with boys. In South Asian region, overall childhood mortality continues to decline, the relative plight of girls has worsened: For example, between the 1970 s and the 1980s, excess mortality among females aged 1 - 5 years increased from $11 \%$ to $28 \%$ in India and from $8 \%$ to $22 \%$ in Nepal (Agnihotri, 1995). Son preference may be a direct contributing factor, through shortened birth intervals after the birth of girls (Choe, 1998) and the neglect of younger daughters in large families of girls in which parents are still hoping for a boy (Clark, 2000). Son preference may also promote more extreme forms of discrimination, such as feticide or infanticide of females (Karki, 1992).

The Cairo International Conference on Population and Development in 1994, and the Beijing Conference on Women and the Girl Child in 1995, gender equality has been a priority area of demographic research. In the South Asian context, researchers have estimated that there are millions of women "missing" from the population, leading to an unusually high ratio of males to females (Agnihotri, 1995). Failure to report the birth of girls, sex-selective abortion, neglect of daughters and female infanticide may all play a role.

The sons are very highly prized and daughters are desired because sons continue the family name, continue their lineage, transfer of parental properties in lineage system, can perform funeral rituals are and expected to provide support in old age. This patrilineal social structure discourages women from practicing contraception until they have a son (Karki, 1992). The son preference may exert an influence not only on contraceptive use and fertility levels, but also on the progress of fertility decline.

\section{Theoretical Framework}

In many societies, son preference is so common and sex-selective practices so strong that, at the population level, the number of boys being born is much greater than the number of girls. Moreover, only sons carry out certain functions under religious and cultural traditions, such as death rituals for parents.

"Society is a kind of organism" propounded by Auguste Comte revived analo- 
gies made by the Greeks and closer to his time, by Hobbes and Rousseau. Comte effectively linked sociology with the prestige of biological science. For functional theory, then, society is like a biological organism that grows, and as a consequence, its parts can be examined with respect to how they operate (or function) to maintain the viability of the body social as it grows and develops. Functionalist analyses therefore, examine the social significance of phenomena, that is, the purpose they serve a particular society in maintaining the whole (Craib, 1997).

In Herbert Spencers' terminology functionalism is an ethnographic school that studies human and his/ her behaviour and associates in integrative way using scientific methods. Spencer's theory is filled with analogies between organisms and society as well as between ecological processes (variation, competition, and selection) and societal evolution (which he saw as driven by war). Spencer did not see society as an actual organism; rather, he conceptualized "super organic systems".

Later functionalists produced somewhat different lists of requisites. Émile Durkheim argued that sociological explanations "must seek separately the efficient cause of a phenomenon and the function it fulfills" (Craib, 1997), but, in contrast to Spencer, he posited only one functional requisite: the need for social integration. For Durkheim, then, sociological analysis would involve assessment of the causes of phenomena and their consequences or functions for meeting the needs of social structures for integration.

Malinowski suggested that individuals have physiological needs and to satisfy that individuals' need social institutions play key roles to satisfy theses needs. So, social institutions are developed to satisfy or to meet these needs. There are also culturally derived needs and four basic "instrumental needs" (economics, social control, education, and political organization), that require institutional devices. Each institution has personnel, a charter, a set of norms or rules, activities, material apparatus (technology), and a function (Craib, 1997). Malinowski believed that uniform psychological responses are correlates of physiological needs.

Radcliffe-Brown suggested that a society is a system of relationships maintaining it through institutions that are orderly sets of relationships whose function is to maintain the society as a system. At the same moment, the views of non-Western (i.e. south Asian) philosophers and scholars are mainly based on religion. Since religions do not change, so philosophies based on religion do not change as well, except in the form of interpretation and re-interpretation. Radcliffe-Brown, following Auguste Comte, believed that the social constituted a separate "level" of reality distinct from those of biological forms and inorganic matter. Furthermore, he believed that explanations of social phenomena had to be constructed within the social level. He believed that individuals were replaceable, transient occupants of social roles. Unlike Malinowski's emphasis on individuals, Radcliffe-Brown considered individuals irrelevant (Craib, 1997). He argued that satisfaction of these needs transformed the cultural instrumental activity into an acquired drive through psychological reinforcement. 
Social justice and social morality are the fundamental theme and has been concerned of Sociology since the period of Marx, but, abuse of concepts of biology especially evolutionary biology or biosociology in the context of explaining cultural, racial and gender based similarities and differences. Evolutionary sociology and biosociology are based on the fact that in their genes and other evolved traits, all humans are more similar than they are different. Genetically all humans share the same genes, with only small differences in gene variants between individuals and between groups (Witherspoon et al., 2007). The biological unity of humanity that underlies evolutionary sociology and biosociology is compatible with most moral codes based on the essential equality of all, including the United Nations Declaration of Human Rights, and most religious codes. Further, it is likely that many of the common social biases that are found cross-culturally, e.g., racial and gender-based biases, have an evolved on these bases (Banaji \& Greenwald, 2013). Understanding how evolved genes and traits influence social behavior (and vice versa) can help us better understand the social world. Among these various differences gender based differences and inequalities are the most important factors that's why in this paper these emerging issues of gender based differences in relation with son preference can be visualized by various theoretical frame work among them;

\subsection{Social Darwinian Perspective; Theory of Gene and Cultural Variations}

Social Darwinism is the Darwinian principle propounded by Herbert Spencer on the basis of Darwin's concepts of Natural Selection through the survival of the fittest. This ideology was used to justify differences in terms of cultural behaviors-material and non material cultures-technology, inventions, cultures, society, traits, norms, values, attitudes based on biological factors like; gene, race, gender, geography, climate etc based their adaptations.

The biologically, genes are unit of heredity which is transferred from a parent to offspring and is held to determine some characteristic of the offspring i.e. gene is a component that determine what the organism is exactly like, its appearance, how it survives, and how it behaves in its environment. Genes are made of a substance called deoxyribonucleic acid, or DNA. They give instructions for a living being to make molecules called proteins. But genes do not behave, animals do, because animals live or die, reproduce or not, depending on their fitness with the environment and genes usually select indirectly. The behavior and other Modern human behavior can be and has been subjected to game theory for their gene selection through completions and optimality modeling, and some predictions have been confirmed (Daly \& Wilson, 1988). In this sense, human society is no more than one example from among many and it becomes an object of research for biosociology, which has its roots in two types of sociology: sociology of the inter-species, and sociology of the intra-species. The former considers geographical and later historical factors, in contrast, includes the level 
of the individual organism and a society of species.

Culture can evolve through similar processes to genetic evolution: cultural variants can have differential survival and reproduction, but there are notable differences between cultural transmission, mutation, and inheritance and their genetic analogues (Mesoudi, 2016). Cultural transmission cannot juxtapose the theory of hybridization that Mendel propounded to explain the inheritance on single genes, and it may occur between unrelated individuals. Culturally transmitted traits, such as norms, values, attitudes, role and preferences, can change within the course of a human generation, and cultural inheritance may occur over many generations, between groups rather than individuals, and depend on the environmental or social context in which an individual lives.

Consanguinity and the cultural practices through the socialization is a culturally transmitted behavior that leaves an identifiable signature on the human genome in one hand and enculturation, assimilation are another which also play as agents to transmit the culture from one to another. Other aspects of human culture, such as religion (Haber et al., 2013) and sex-specific demographic features (Heyer et al., 2012), including sex-biased migration and sex-specific definition of cultural belonging, can also shape a population's trajectory of genetic evolution. By separately tracing the evolution of maternally transmitted mitochondrial sequences and paternally transmitted Y chromosomes, researchers can test the genetic effects of cultural practices such as matrilineality and patrilineality (Underhill \& Kivisild, 2007), as well as other sex-biased patterns of human demography that are culturally determined.

Although the basic postulates of natural selection are elegantly parsimonious, their application to social behavior in general, and to human social behavior in particular, is enormously complex. Phenotypes, whether morphological or behavioral, are the product of the interaction of genotype and environment. Many, if not most, behavioral traits are probably controlled by a multiplicity of genes through gradual changes in relation to environmental adaptation, use and disuse of the organs, hybridization, mutations or by any other means and many genes probably have multiple effects. As for "environment", the word is but a shorthand term that subsumes a vast array of factors including the complex interaction effect of genes (which constitute a kind of internal environment for each other), the physical milieu, the biotic environment (including our own end parasites) and, last but not least for humans, the socio-cultural environment.

Individual fitness or say Darwinian fitness refers to the success of an individual in contributing its genes to the next generation by reproduction, and inclusive fitness refers to the sum of an organism's individual fitness plus that organism's contribution to the fitness of its relatives other than direct descendents. Thus, inclusive fitness is increased by the process of kin selection.

\subsection{Sociobiological Perspective;}

The objective of this article is to trace out the evolutionary biological studies of 
sex-biased post-natal parental investment that may be relevant to the issue of preconception gender selection. This also helps to predict that natural selection has favored parents that bias investment in favor of the sex with the best reproductive prospects. Because resource abundance and scarcity often have greater effects on male than on female reproductive success, that natural selection will most often favor parents who favor males when conditions are good and females when conditions are poor.

The son preference is prevalent around the world. Multiple factors either from dowries or to discriminatory inheritance laws help to drive such practices such as female infanticide, deliberate neglect, and abandonment. Sex selection in favor of boys is a symptom of pervasive social, cultural, political and economic injustices against women, and a manifest violation of women's human rights.

Sexual selection refers to the differential ability of individuals with different phenotypes to compete successfully for mates. By producing traits that are attractive to prospective mates, such as brightly colored plumage among male birds, sexual selection increases the chances of an individual's reproductive success. However, the same traits that are favored by sexual selection can be penalized by natural selection, as in the case where brightly colored plumage simultaneously attracts mates and predators. In case of human, mate selection is generally guided by fitted genes in terms of physically, mentally, socio-culturally advances and smarts for individual's reproductive success.

There is one important complication with humans, however, that makes them extend evidently altruistic forms of behavior beyond their biological kin. Because of "psychic unity of mankind" humans have evolved a sufficiently high level of intelligence to recognize each other as individuals and to remember each other's behavior for long periods of time. That is, they are intelligent enough to engage in "reciprocal altruism" (Trivers, 1971). "Reciprocal altruism" is, again, an improper term for human. In fact, they enlightened for their own self interest guided by selfishness. One's favors are extended in the expectation of return from others.

It is assumed that, the evolutionary perspective on human behavior-whether it be called sociobiology, biosociology or whatever-will become equally trite to the social scientist. Historical sociology stands in relation to sociobiology much as, say, meteorology does to physics and computer technology does to information technology. Sociobiology does not offer a simple, mechanical key to the understanding of human behavior and this world. Despite this it provides the new dimensional perspective of extraordinarily complex blend of genetic and environmental factors to understand the human behavior. That's why; Sociobiology does, however, put human behavior in the much wider perspective of the phylogeny of our species, as one among many species that adapted over millions of years to a multiplicity of changing environmental conditions. It puts human behavior in a comparative perspective, and provides us with a general explanation of why our behavior evolved in some respects like that of many other species, in 
some respects like that of a few other species and in some respects in uniquely human ways. It focuses the role or the importance of cultural variability, or the increasing role of technology in widening the limits of our biological constraints.

\subsection{Ecological Perspective; Nature vs Nurture}

Ecology is also another alternative perspective to analyze the human behavior in a wider sense. Ecology acts as a major component of variations; either genetic variation (either by geographical isolation, or by adaptation of species or by origin of new species) or cultural variations. In this context there is interplay between nature and nurture i.e. biology vs sociology in terms of studying of human behavior. Here, nature vs. nurture debate is one of the most common while studying the human behavior. "Nature" refers to biological/genetic predispositions' impact on human traits, and "nurture" describes the influence of learning and other influences from one's environment. The debate over whether the strengths and weaknesses of people are the result of nature or nurture has, and somewhat continues to rage on between scholars and lay people alike. This debate has had significant social implications, particularly concerning what are thought to determine people's ability to learn/intelligence.

Ecological constraints affect parental behavior and the differential treatment of sons and daughters. Cross-culturally, female infants and fetuses are at risk only under certain particular and predictable cultural-ecological conditions such as plow agriculture, herding, patrilineal inheritance, dowry, and low resource contribution by women (Bugos \& McCarthy, 1984).

There is, thus, nothing in sociobiology that denies the importance of the environment, the uniqueness of humans in some crucial respects or the flexibility of individual adaptation through culture. Sociobiology is sometimes misrepresented as advocating a rigidly deterministic model of human behavior in response to a narrow repertoire of "instincts", whereas, in fact, it merely urges us to look at ourselves as one biological species among many, with our unique evolutionary history of adaptation to specific ecological niches. It rejects a dualistic view of heredity versus environment, nature versus nurture, and substitutes an integrated view of human behavior as the complex product of the interaction between genotype and environment in response to a multiplicity of selective pressures, many of them manmade. Sociobiology sees human language and culture as extremely important, but as being themselves the outcome of a process of biological evolution. Culture, to be sure, is partially independent of our genotype, but continues to interact reciprocally with both our genotype and our physical and biotic environment (Van Den Berghe, 1978).

\subsection{Economic and Demographic Perspective}

In most of the societies, the family plays a fundamental role in reproducing the divisions, as well as the hierarchy, between the different social classes and genders to which different social and economic functions are assigned. In the name of 
the "maternal" function, women must take on all the tasks related to maintaining and reproducing the workforce and the family. As for men, they are always supposed to be the main economic purveyors. All this makes it possible, in the context of professional segregation and in the name of the so-called complementary roles, to carry on underpaying women on a discriminatory basis.

Family also plays its part in "regulating" the labor market. In times of economic expansion, as was the case for about thirty years until the early 1970s, women are massively called upon as cheap labor in a number of manufacturing industries such as electronics, then as wage-earners in the service industry. But in times of economic recession, as over the last thirty years, employers and the State unrelentingly suggest that women should-partly or completely-withdraw from the labor market to devote themselves to their "natural" vocation as mothers. When there are signs of economic recovery (however short-lived), some collective investments are again considered, not with regard to gender equality, but in order to "release" female labor and subject it to flexible schedules.

In a classical history of economic measurement, it is found that over time, markets had developed for some household activities-such as restaurants for meals out and that women moved into the paid workforce during wartime then out of it again afterward; hence, the omission of unpaid services of housewives from national income computation distorts the picture. The unpaid work in the home should be included in GDP, but there were practical difficulties in estimating the amount of work and its valuation. Given that there are practical difficulties in every aspect of gathering data to estimate GDP, it is hard to avoid the suspicion that in the end this just was not seen as a sufficiently (Studenski, 1958).

Sexual economics theory rests on standard basic assumptions about economic marketplaces, such as the law of supply and demand. When demand exceeds supply, prices are high (favoring sellers, that is, women). In contrast, when supply exceeds demand, the price is low, favoring buyers (men).

The economic theory emphasized on the differentiation on sex role in economy (Baumeister \& Vohs, 2004). They emphasized on buying and selling as explaining sexual economics theory as a framework for exploring how men compete against other men to get a good woman, and, perhaps even more important, how women compete against other women to get a good man. Before going to elucidate the economic value of men and women, it is necessary to revise and update sexual economics theory, including specifying that often what is sold is not just sex but exclusive access to sex with a particular person. The focus of sexual economics theory applies the logic and principles of economic marketplaces to the onset of sexual intercourse among heterosexual couples. The core idea is that women are the sellers and men are the buyers. This starts with the abundant evidence that "everywhere sex is understood to be something females have that males want" (Symons, 1979).

Economic capital signifies money, property, or other financial assets that in- 
dicate one's class and status. In this article, economic capital is discussed in relation to dowry, parents investing money on their children, and parents receiving financial support from their children, mainly sons.

\subsection{Gender Perspective}

Theoretically, the gender theory emphasized on the concept of gender conditioning, gender based division of labor, role of socio-structural and psychological factors for the determining gender status and role in society. Lynn Bennett adapts Mary Douglas's notion "power and dangers credited to social structure are reproduced in small in the human body" and the notion that menstruation restrictions are seen as a means of controlling of danger in society (Bennett, 1983). Agreeing with Sandy's theory of "female power and male dominance", Bennett argued that, in Hindu society, cultural and social factors by projecting various myths, ethos, religions weenies, etc. try to control the female sexuality as dangerous forces in the name of menstrual pollution and purity.

There is always opposition between two contradictory roles in dharma or religion or merit making. She also mentioned about the opposite or anti-thesis between "life cycle" and ascetic life (no sex life) or Sanskrit life vs liberal life, religious purity vs pollution and conditional immorality (worshipping deities for giving birth of son) vs women's oppressions etc where main concerns of Bennett is that there are two opposing ideologies, attitudes in Hindu religions, one may contradict another. But without any one of these may not balance and order the Hindu life. In Hindu society merit making (Dharma Kamayune) in one is the symbol of purity, while non-merit making (Pap Garune) is the symbol of pollution, through which social roles are determined and controlled in this sense Hindus are always try to get "heaven place" by merit making; through which male and patriarchal ideology (followed by mother-in-laws) control the Hindu women's mobility and sexuality.

Tension between mother-in-laws and daughter-in-laws, we expand; when a daughter-in laws first child (especially son) often marks a crisis point out in the relationship of them. The daughter-in-law stops to serve her mother-in laws when she gives birth a child either due to shy or due to increasing work load (Bennett, 1983). But, after two or more than two children especially sons, her status has increased, considerably, and she may feel that, the authority of her mother-in-laws no longer has to be accepted without question. In my opinion, there is conflicting relationship between affinal women, one is a mother-in law and other is daughter in-laws. They mistrust one another, because both want to enjoy power, authority and opportunity within family guided by patriarchy and male. Usually, mother-in-law feels that, her investment on her son, will be stolen by her daughter-in-law and she charges her. This type gender socialization is institutionalized in family and kinship and usually, parents are normally the first and most crucial agents of socialization; they guide children into gender roles deemed appropriate by society. That's why; Bennett tries to show how women's 
social roles in Hindu kinship and family structure are related to their symbolic roles in cultural, economic and social sphere of life in Hindu society (Bennett, 1983).

Thus, in this study, social capital could be understood as women receiving support from their sons; and brothers and sisters having healthy relationships. In this article, internalization can be understood as the acceptance of patriarchal socio-cultural beliefs, values, and norms that individuals learn through their experiences of socialization. Women apply these values and beliefs to themselves and other women and consider men to be socially superior, while regarding themselves as inferior and dependent. Institutions such as family and marriage maintain the norms of gender inequality and reproduce them in daily socio-cultural interactions.

From above discussion, it is concluded that there are inter play between gene, ecology, evolutionary history, economy, demography etc and other human associated components, in which one inter play with one another reciprocally.

\section{Methodology}

This research was conducted in Kathmandu based hospitals where the pre natal care facilities were available, from August 2019 to February 2020.

During the course of this qualitative study semi-structured interviews were carried out among 30 married and educated middle-class mothers in Kathman$\mathrm{du}$ from three hospitals and nursing homes. This information on maintaining confidentiality was provided to the participants both orally as well as through the information sheet. I have preserved the identity of my participants by using pseudonyms. I have changed the identification details of my participants such as their field of work and studies to preserve their anonymity.

Interviews were conducted in Nepali language with respondents of educated middle-class married women with children who had either had an abortion or whose first child was a daughter. I preferred to interview those middle-class women who had at least high school passed (twelve class passed or attended) because, an increased female literacy rate is closely linked with an increased rate of female feticide (Talwar \& Meenu, 2014).

The sample respondents have access to and knowledge of ultrasound and sex-selective abortions, which means that various social factors including family size and sex composition and ratio are not an issue of inconsistency between the educated and wealthy couples (Sabarwal \& Santhya, 2012). Because of this, it is often argued that the rate of domestic violence against women in the context of son preference among the educated middle-class is relatively low.

\section{Socio-Economic Status of the Respondents}

Respondents of age above 20 from middle-class backgrounds were selected, who were visited hospitals for their pre natal care from three different hospital and nursing care. Among the 30 respondents, 10 respondents from each hospital or 
nursing homes were taken as sample survey. In this research both working and non working women were incorporated as respondents because it was very difficult to divide the respondents as in the various strata so as to difficult to gather information as per the research objectives.

The socio-economic status of all 30 respondents of three hospitals or nursing homes, were found very small size nuclear having mostly one child and waiting to have next child. They all respondents were in pre natal care of their pregnancy of $4^{\text {th }}$ months of pregnancy to onwards for the next child. Among 30 respondents, 18 respondents had a daughter as first child and expected to give birth a son as next baby, while 12 respondents had a son as a first child at the time of field work.

In this study, while defining, middle-class as those who have easily satisfied their basic needs and have more than the basic necessities of life (food, clothes, and shelter) such as a car/motorcycle, mobile phone, laptop, air-conditioner, and fridge TV etc. accessories and home appliances with their satisfied job and easily sustained financial conditions. Middle class in Kathmandu is defined as originally inhabitants of Kathmandu; family of business, educated, entrepreneur, traders, employee, politicians, and families migrated to Kathmandu as neo- class from rural areas of Nepal. It is important to note that the new middle-class group shows similarities in ideas about gender relations and patriarchal values are common to the new middle-class.

The economic status of respondents has income ranges from the 500,000 to above per annum. Because of their financial status, all of the respondents were able to access different reproductive health services available in the markets to achieve their interests mainly associated with the son preference. Among 30 respondents, 25 were Hindu and 5 were Buddhist religion base.

\section{Findings and Discussion}

According to the cultural ecological perspective, son preference leads to differential allocation of land resources to sons. One of the main reasons for son preference among middle class families in Kathmandu is to have a son who can take care of the land because males are assigned as productive role or task outside the household in society. In this study, respondents were given a clear version on the distribution of lands, house, industries, properties to the son rather than daughter because, in filiafocal practice, usually, daughters were given love, respect, gift, kind- dowry, cash, goods rather than the involvement in institutions like; land, factory, etc.

Behavioral ecologists point out that ecological factors influence parental investments, and parents are mostly biased on investment based on sex and they will do their best to allocate resources, opportunities and expend effort for the reproductively most profitable sex (Charnov, 1982). Thus, in polygynous societies, when resources and goods differentially affect men's success in marrying and raising children, inheritance is strongly patrilineal or male biased Cross- 
culturally, among traditional societies, women's ability to control resources, inherit property, and hold political office indeed have ecological correlates (Low, 2000). In case of studying son preferences among middle class educated women respondent it is clearly found that, son preference influences land resource allocation. Here, in the course of field studied in Kathmandu, it is found that, mainly, Brahmin caste is keen interest and rigid to give birth son because of Hindu orthodox values.

Table 1 shows that caste and ethnicity based distribution of 30 respondents provided opinion towards the son performance. Among them 37\% respondents are Brahmin followed by Chhetri which comprises 30\%. All respondents provided their desire to have son was found very high. It is found that in allocating land resources, there will be a stronger preference among middle class families in Kathmandu, to allocate resources to sons among all of them, mostly Newars and Chhetris are holdings land than others like Brahmins and Tamangs. For all caste and ethnicity groups resources usually lands and share of public and private companies were given priority to son rather than daughter. In compensation that daughters were given dowry and some cashes in the form of pewa and gifts.

However, in some cases of big land holders, daughters were given small chunk of land to build house in the cash of marrying with whom is from out of Kathmandu valley or in the case of holding almost no land and house in Kathmandu. Perhaps, the women were under pressure to raise their sons to be successful in order to maximize their chances of finding a partner. In addition, because of patrilocal arrangement, they themselves might not have received any land from their parents. Hence, they may be more inclined to believe that sons should get all or more lands.

It found that psychological antecedents to female neglect and son preference would be caste specific and that a combination of cultural and ecological factors would affect various beliefs about gender. These field studies suggest that, in

Table 1. Distribution of respondents by caste and ethnicity.

\begin{tabular}{cccc}
\hline S.N. & Caste and Ethnicity & Respondent & Percentage \\
\hline 1 & Brahmin & 11 & 37 \\
2 & Chhetri & 9 & 30 \\
3 & Newar & 4 & 13 \\
4 & Tamang & 3 & 10 \\
5 & Rai & 2 & 7 \\
6 & Others & 1 & 3 \\
\hline
\end{tabular}

(Source; Field survey, 2019-2020). 
their resource allocation tasks, educated middle-class of Kathmandu significantly in favoring sons, as well as in attitudes toward female fidelity, culture-ofhonor beliefs, and social distance measures. The overlap between educated middle-class of Kathmandu could be related to ecological changes in the Kathmandu and surrounding area. Their son preference, which originally emerged from their honor culture, has also spread to their attitude toward land holdings.

The patriarch has assets in land resources; share of companies, trading houses, including various resources and cashes. While in sharing parental properties with brothers during separations, Respondents were responded to decide whether the cash should be given to the son who has all daughters and the land should be given to the son who has all sons, or vice versa. If equal distribution is a sole criterion for allocating resources, there should not be much difference between the choices. This dilemma will test whether there is a bias to keep family lands in the possession of male descendents. This dilemma indirectly tests the central role of land in the desire to have more sons. It is found that a significantly higher proportion of respondents would allocate land resource to sons with male offspring and the cash to the son with daughters.

My research concluded that, gender inequality among the educated middle-class of Kathmandu has undergone changes in modern times: position and status of daughters are now being changed gradually once girls are discriminated before birth but not after birth. Both sons and daughters are treated equally by providing same or similar facilities regarding education, and job opportunities with same investment according to their interest and capabilities. This marginal improvement signifies changing attitudes among the middle-class that was found in Kathmandu. Urbanization, female education and employment are slowly changing the gender scripts so that daughters are increasingly perceived as being equally valuable to their families and societies.

The gender differences in beliefs about resource allocation reveal the complex predicaments of women in educated middle-class of Kathmandu. On one hand, these women are expected to be responsible for maintaining cultural continuity, such as the maintenance of the patrilocal transfer of resources. At the same time, such practices also perpetuate the differential treatment of daughters contributing to male-biased sex ratios. The only way women have access to resources in educated middle-class of Kathmandu is by ensuring the patrilocal transfer of family resources. In addition, in patrilineal societies, women gain fitness through grandsons. Hence, preserving land resources for the male lineage may be more critical for women than for men.

Ecological factors influence the differential treatment of sons of daughters and extreme forms of gender discrimination leading to male-biased sex ratios. There are several consequences. Male-biased sex ratios could contribute to a culture that valorizes masculine and feminine beliefs. Fraternal polyandry may be another option (Goldstein, 1971; Goldstein, 1976).

In case of mate selection, men have to be successful and competitive in order 
to find a mate, while, the socioeconomic mobility of women seems to have a paradoxical effect on the treatment of daughters in new socio-natural environment. Since others in educated middle-class of Kathmandu are under tremendous pressure to ensure the financial and academic success of their sons, highly educated women in male-biased sex ratio in educated middle-class of Kathmandu tend to invest more in their sons than in their daughters. It seems that a combination of economic success and internalization of idealized notions of masculinity may improve the reproductive success of men among educated middle-class of Kathmandu. However, such idealized notions of masculinity could also be a source of stress affecting the psychological well being of men (Das Gupta \& Visaria, 1996, Mahalingam, 2007).

Similarly, it is found that women and patriarchy are playing key role to establish the son performance in educated middle-class of Kathmandu. Institutions of society, such as family and marriage perpetuate the norms of gender inequality and reproduce them in daily interactions between men and women. The absence of a son leads family members and social networks to put pressure on women to have a son, affecting their reproductive choices. It also mentioned that during the field work respondent considered socially constructed gender inequality as normal and natural and legitimized it through their son preference practice. Even respondents did not challenge their subordination and dependence upon men and instead considered them socially and biologically weaker and inferior to men.

\subsection{Religions and Son Preference}

Funtionalists and their followers believe on religion as an organ in organism, a sub-system within the system, an interlocking and necessary institution, which plays a role in the creation and maintenance of the value consensus. Similarly, Marxist and their followers believe on that religion is formed so as to create the inequality in societies through idea of "ruling class" over "ruled class".

A religious difference in son preference remains strong and significant after controlling for socioeconomic determinants of son preference, and suggests that religious identity, beliefs and practices may be a key cultural explanation for the persistence of son preference, within the demographic literature, there has been a long-standing interest in understanding the influence of religion on fertility (Goldscheider \& Uhlenberg, 1969), who indicated that there may be multiple sources for fertility differences between different religious groups. These may relate to differences between religions groups in underlying socioeconomic characteristics, the particular tenets of a religious group which pass value judgments or prescribe appropriate actions on marriage, contraception and childbearing, as well as the effect of minority group status on a community's integration in society and its impact on fertility preferences.

Table 2 shows that, even if in any religion, there is a culture of son preferences that are prevailing even though any kind of religious perception, 
Table 2. Distribution of respondents by religions.

\begin{tabular}{cccc}
\hline S.N. & Religions & Respondent & Percentage \\
\hline 1 & Hindu & 23 & 77 \\
2 & Buddhist & 5 & 17 \\
3 & Christians & 1 & 3 \\
4 & Muslim & 1 & 3 \\
& Total & 30 & 100 \\
\hline
\end{tabular}

(Source; Field survey, 2019-2020).

values, attitudes, norms and traits. It is known from the above table that, middle class family in Kathmandu is predominantly Hindus and they mostly follow the Hindu values and norms in which son is the means through which the path towards heaven is easy and sure. The table presented the distribution of respondent according to the religions comprise; 77\% Hindu, followed by Buddhists $17 \%$. It showed that religion is the key factor to select sex of child according to their religious values. All regions are same in the context of gender discriminations mostly the son gets high value and daughter gets low. Role of religion is not towards the gender balance in role, rights, responsibly and authority. Male stands for ruling class and female for ruled class.

\subsection{Economics and Son Preference}

Occupational structure is undoubtedly implicated in a variety of socioeconomic phenomena relating to economic development and social inequalities (Grusky et al., 1984). Social strata is mainly determined by their occupations, since occupation reflects the individual's position in the technical division of labor, occupational structure is often construed to represent the pattern of socioeconomic opportunity in modern societies (Rose \& Harrison, 2009). In another way, occupational structure also relates to the level of discrimination and segregation of various social groups (by gender and race) since occupational attainment is rarely determined solely by an individual's choice alone (Gill, 1989). Moreover, changes in the occupational structure are related to changes in the demand for different occupational services due to socioeconomic development and technological advances (Blau et al., 1967). Since technological development affects the division of labor, it impacts almost every aspect of the social structure (Williams, 1979). There are various cross-national comparisons studies have improved our understanding of the levels of social inequality between countries as well as between various social groups within countries (Rose \& Harrison, 2009).

Sex differences are usually shaped by the processes of sexual selection, intersexual selection and intersexual competition. In most species, males make a smaller parental investment than females and females tend to be more discriminating in mate choice because of their greater costs of reproduction. As a result, the reproductive success of males depends largely on their ability to compete for 
mating opportunities, whether by winning fights with other males, competing for social status or territory, or by presenting displays preferred by females (Darwin, 1871; Trivers, 1972). Males who succeed in these competitions have more offspring, and this shapes traits that foster such success, even if those traits also lead to physiological and behavioral differences that make males more prone to injury, sickness and early death. Relative to females, the optimum balance of investment for males is shifted towards reproductive effort and away from somatic effort (building up the body and maintaining health), and towards mating effort at the expense of parental effort.

Because males benefit more so from numerous mating opportunities than do females, they were selected to invest more effort in mating than females, while females allocate proportionally more effort to improve the quality of their offspring.

Table 3 shows that, respondents who prefer son as her child mostly from the occupation of private job holders who can earn money satisfactorily. In middle class families in Kathmandu, people want mostly single child or sometimes two children. In job market accepts few; mostly wages for male sex is higher than female. From the economic point of views, male has unlimited capacity to produce, reproduce that's why they want male, while to get female is normal but getting male is rare. Above table shows clear cut distribution of respondent by occupations. The data presented in the above table shows that, occupation is another component on determining the sex of child which they want to born. Usually, respondents in the study area were asked," what is the opinion of your husband, about selection of gender as your forthcoming child"? They clearly responded that they both wanted a son that's why they are now in the process of getting him very soon. In response to why you want to get a son rather than daughter? Most of the respondent replied that, "son is a son who will handle all works very comfortable, successfully, because they are brave and they can handle everything very easily now and they will take care of all in old age while we will not able to do any task and care ourselves". One of the respondents replied me when I asked her the question; why you need son, why not daughter? "Son is

Table 3. Distribution of son preference respondents by occupation.

\begin{tabular}{cccc}
\hline S.N. & Occupations & Respondent & Percentage \\
\hline 1 & Factory Production & 1 & 3 \\
2 & Trading/ business & 6 & 20 \\
3 & Entrepreneur & 4 & 13 \\
4 & Government job & 4 & 13 \\
5 & Suppliers & 5 & 17 \\
6 & Private job & 10 & 34 \\
& Total & 30 & 100 \\
\hline
\end{tabular}

(Source; Field survey, 2019-2020) 
essentially significant in our culture, they can continue our lineage, take care our parental properties, and status of parents what they earned during their life. Son only can worship and remember our soul after death".

\section{Conclusion}

A cultural ecological perspective is valuable in identifying the complex relationship among ecology, culture, society, economy, demography and preference of particular gender especially male preferences. An evolutionary psychology explanation of female infanticide should take into account the role of cultural practices and ecological pressures in shaping psychological antecedents to treating differently even for own genes i.e. male preference and female neglect. In this regards, the relationship between ecology and culture is dynamic, and that macro interventions, such as building of cities, urbanization, development of highways, constructions of high dams in a physical development and advancement of socio-economic parameters associated with human development including leadership development, sustainability, sustainable use of resources, maintain equilibrium among population and resources and opportunities including empowerment of women, ultimately resulting in tightening the screw of social control of women's sexuality. Women's preference to marry up (hypogyny) further contributes to intense male-male competition among educated middle class of Kathmandu. It is found that, the complex interaction between ecology, cultural practices, and attitudes are deeply rooted toward gender among them.

Last but not least, it is found that educated middle-class Kathmandu based women have internalized there in equality, discrimination and subordination to such an extent that they view their existence in relation to the men and in their surroundings as components of ecosystem. There should maintain delicate balance between the relationship between women-men, women-women, and men-men, economically, demographically, socially, physically ecologically biologically or say culturally symbiotic in various forms as a husband or a son or a brother. By accepting their subordinate status, women often receive socio-cultural benefits such as prestige and honor among their social networks and families, old-age support, financial support, and male protection. Simultaneously, they can protect themselves from forms of social criticism and resistance. These advantages increase women's statuses at the social level, but do not alter their subordinate position in society and the gender hierarchy culturally.

From the study, it is concluded that, though society and culture are modern, heterogeneous, complex, advancing the conservative or traditional practices of son preference or discrimination based on gender are still practiced and are prevalent in our society and continue to define gender roles and practices especially among the middle-classes that found in Kathmandu. Therefore, son preference, for the middle-class women in Kathmandu should not be understood superficially. It is a complex whole and it should be studied comprehensively and 
critically through the integrated approaches.

\section{Conflicts of Interest}

The author declares no conflicts of interest regarding the publication of this paper.

\section{References}

Agnihotri, S. B. (1995). Missing Females: A Disaggregated Analysis. Economic and Political Weekly, 30, 2074-2084.

Banaji, M., \& Greenwald, A. (2013). Blindspot: Hidden Biases of Good People. New York: Delacorte Press.

Baumeister, R. F., \& Vohs, K. D. (2004). Sexual Economics: Sex as Female Resource for Social Exchange in Heterosexual Interactions. Personality and Social Psychology Review, 8, 339-363. https://doi.org/10.1207/s15327957pspr0804_2

Bennett, L. (1983). Dangerous Wives and Sacred Sisters: Social and Symbolic Roles of High Caste Women in Nepal. New York: Columbia University Press.

Blau, P., Duscan, M., \& Dudley, O. (1967). The American Occupational Structure. New York: John Wiley \& Sons.

Bugos, P. E., \& McCarthy, L. M. (1984). Ayoreo Infanticide: A Case Study. In G. Hausfater, \& S. B. Hrdy (Eds.), Infanticide: Comparative and Evolutionary Perspectives (pp. 503-520). New York: Aldine.

Charnov, E. L. (1982). The Theory of Sex Allocation. Princeton, NJ: Princeton University Press.

Choe, M. K. et al. (1998). Son Preference, Family Building Process and Child Mortality. In Too Young to Die: Genes or Gender (pp. 208-222). New York: United Nations Publication.

Clark, S. (2000). Son Preference and Sex Composition of Children: Evidence from India. Demography, 37, 95-108. https://doi.org/10.2307/2648099

Craib, I. (1997). Classical Social Theory. London: Oxford University Press.

Dalla Zuanna, G., \& Leone, T. (2001). A Gender Preference Measure: The Sex Ratio at Last Birth. Genus, 57, 33-57.

Daly, M., \& Wilson, M. (1988). Evolutionary Social Psychology and Family Homicide. Science, 242, 519-524.

Darwin, C. (1871). The Descent of Man and Selection in Relation to Sex. London: John Murray. https://doi.org/10.5962/bhl.title.2092

Das Gupta, M. (1987). Selective Discrimination against Female Children in Rural Punjab, India. Population and Development Review, 13, 77-100.

https://doi.org/10.2307/1972121

Das Gupta, M., \& Visaria, L. (1996). Son Preference and Excess Female Mortality in India's Demographic Transition. In Sex Preferences for Children and Gender Discrimination in Asia (pp. 6-102). Seoul: Korea Institute for Health and Social Affairs, UNFPA.

George, S. (1997). Female Infanticide in Tamil Nadu, India: From Recognition Back to Denial? Reproductive Health Matters, 5, 124-132. https://doi.org/10.1016/S0968-8080(97)90093-8

Gill, A. M. (1989). The Role of Discrimination in Determining Occupational Structure. 
Industrial and Labor Relations Review, 42, 610-623.

https://doi.org/10.1177/001979398904200410

Goldscheider, C., \& Uhlenberg, P. R. (1969). Minority Group Status and Fertility. American Journal of Sociology, 74, 361-372. https://doi.org/10.1086/224662

Goldstein, M. C. (1971). Stratification, Polyandry, and Family Structure in Central Tibet. Southwestern Journal of Anthropology, 27, 64-74. https://doi.org/10.1086/soutjanth.27.1.3629185

Goldstein, M. C. (1976). Fraternal Polyandry and Fertility. Human Ecology, 4, 223-233. https://doi.org/10.1007/BF01534287

Grusky, D., Hauser, B., \& Robert, M. (1984). Comparative Social Mobility Revisited: Models of Convergence and Divergence in 16 Countries. American Sociological Review, 49, 19-38. https://doi.org/10.2307/2095555

Haber, M., Gauguier, D., Youhanna, S., Patterson, N., Moorjani, P., Botigué, L. R., Daniel, E., Platt, D. E., Smith, E. M., Soria-Hernanz, D. F., Wells, R. S., Bertranpetit, J., Chris Tyler-Smith, C. T., Comas, D., \& Zalloua, P. A. (2013). Genome-Wide Diversity in the Levant Reveals Recent Structuring by Culture. PLOS Genetics, 9, e1003316.

https://doi.org/10.1371/journal.pgen.1003316

Heyer, E., Chaix, S., Pavard, R., \& Austerlitz, F. (2012). Sex-Specific Demographic Behaviours That Shape Human Genomic Variation. Molecular Ecology, 21, 597-612. https://doi.org/10.1111/j.1365-294X.2011.05406.x

Karki, Y. B. (1992). Sex Ratio in Nepal. Economic Journal of Nepal, 15, 30-37. https://doi.org/10.3126/jcmsn.v15i1.20753

Low, B. S. (2000). Why Sex Matters. Princeton, NJ: Princeton University Press.

Mahalingam, R. (2007). Beliefs about Chastity, Machismo and Caste Identity: A Cultural Psychology Perspective. Sex Role, 56, 239-249.

https://doi.org/10.1007/s11199-006-9168-y

Mesoudi, A. (2016). Cultural Evolution: Integrating Psychology, Evolution and Culture. Current Opinion in Psychology, 7, 17-22. https://doi.org/10.1016/j.copsyc.2015.07.001

Miller, B. (1997). The Endangered Sex: Neglect of Female Children in Rural North India. Delhi: Oxford University Press.

Mitra, A. (2014). Son Preference in India: Implications for Gender Development. Norman, OK: Department of Economics, University of Oklahoma.

Pradhan, A., Aryal, R. H., Regmi, G., Ban, B., \& Govindasamy, P. (1997). Nepal Family Health Survey 1996. Kathmandu: Ministry of Health, Calverton, MD: New Era, and Macro International Inc.

Puri, M., Ingham, R., \& Matthews, Z. (2007). Factors Affecting Abortion Decisions among Young Couples in Nepal. Journal of Adolescent Health, 40, 535-542. https://doi.org/10.1016/j.jadohealth.2007.01.010

Rose, D., \& Harrison, E. (2009). Social Class in Europe: An Introduction to the European Socio-Economic Classification (p. 324). London: Routledge.

Sabarwal, S., \& Santhya, K. G. (2012). Treatment-Seeking for Symptoms of Reproductive Tract Infections among Young Women in India. International Perspectives on Sexual and Reproductive Health, 38, 90-98.

Studenski, P. (1958). The Income of Nations (p. 554). New York: New York University Press.

Symons, D. (1979). The Evolution of Human Sexuality. New York: Oxford University Press. 
Talwar \& Meenu (2014). State of Primary Education in Punjab. International Journal of Social Science and Humanities Research, 2, 1-10.

Trivers, R. (1971). The Evolution of Reciprocal Altruism. Quarterly Review of Biology, 46, 35-57. https://doi.org/10.1086/406755

Trivers, R. (1972). Parental Investment and Sexual Selection, In B. Campbell (Ed.), Sexual Selection and the Descent of Man: 1871-1971 (pp. 136-179). Chicago, IL: Aldine. https://doi.org/10.4324/9781315129266-7

Underhill, P. A., \& Kivisild, T. (2007). Use of Y Chromosome and Mitochondrial DNA Population Structure in Tracing Human Migrations. Annual Review of Genetics, 41, 539-564. https://doi.org/10.1146/annurev.genet.41.110306.130407

Unnithan-Kumar, M. (2005). Introduction. In M. Unnithan-Kumar (Ed.), Reproductive Agency, Medicine and the State (pp. 1-24). New York, Oxford: Berghahn Books.

Unnithan-Kumar, M. (2010). Female Selective Abortion-Beyond "Culture": Family Making and Gender Inequality in a Globalising India. Culture Health and Sexuality, 12, 153-166. https://doi.org/10.1080/13691050902825290

Van Den Berghe, P. L. (1978). Sociobiology: A New Paradigm for the Behavioral Sciences? Social Science Quarterly, 59, 326-332.

Williams, G. (1979). The Changing U.S. Labor Force and Occupational Differentiation by Sex. Demography, 16, 73-87. https://doi.org/10.2307/2061080

Witherspoon, D. J., Wooding, S., Rogers, A. R., Marchani, E. E., Watkins, W. S., Batzer, M. A., \& Jorde, L. B. (2007). Genetic Similarities within and between Human Populations. Genetics, 176, 351-359. https://doi.org/10.1534/genetics.106.067355 